\title{
High levels of serum IL-6 and serum hepcidin and low CD4 cell count were risk factors of anemia of chronic disease in HIV patients on the combination of antiretroviral therapy
}

This article was published in the following Dove Press journal:

HIVIAIDS - Research and Palliative Care

\author{
I Ketut Agus Somia' \\ Tuti Parwati Merati ${ }^{\prime}$ \\ I Made Bakta ${ }^{2}$ \\ Ida Bagus Putra Manuaba ${ }^{3}$ \\ Wayan Putu Sutirta Yasa ${ }^{4}$ \\ I Dewa Made Sukrama ${ }^{5}$ \\ Ketut Suryana ${ }^{6}$ \\ Rudi Wisaksana $^{7}$ \\ 'Division of Tropical and Infectious \\ Disease, Department of Internal \\ Medicine, Udayana University-Sanglah \\ Hospital, Denpasar, Bali, Indonesia; \\ ${ }^{2}$ Division of Hematology and Medical \\ Oncology, Department of Internal \\ Medicine, Udayana University-Sanglah \\ Hospital, Denpasar, Bali, Indonesia; \\ ${ }^{3}$ Chemistry Department, Faculty of Math \\ and Science, Udayana University, \\ Denpasar, Bali, Indonesia; ${ }^{4}$ Department \\ of Clinical Pathology, Udayana \\ University-Sanglah Hospital, Denpasar, \\ Bali, Indonesia; ${ }^{5}$ Department of Clinical \\ Microbiology, Udayana University-Sanglah \\ Hospital, Denpasar, Bali, Indonesia; \\ ${ }^{6}$ Division of Allergy and Immunology, \\ Department of Internal Medicine, \\ Udayana University-Wangaya Hospital, \\ Denpasar, Bali, Indonesia; ${ }^{7}$ Division of \\ Tropical and Infectious Disease, \\ Department of Internal Medicine, \\ Padjajaran University, Bandung, West \\ Java, Indonesia
}

Correspondence: I Ketut Agus Somia Division of Tropical Infectious Disease, Department of Internal Medicine,

Udayana University-Sanglah Hospital,

Diponegoro street, Dauh Puri Klod, West

Denpasar, Denpasar, Bali 80II3, Indonesia

Tel +628123989353

Email agus.somia@unud.ac.id
Purpose: This study aimed to determine whether high levels of serum IL-6 and serum hepcidin and CD4<350 cells/ul were risk factors for the anemia of chronic disease (ACD) in HIV-infected patients on the combination of antiretroviral (cARV) therapy with successful clinically and immunological responses.

Patients and Methods: A matched case-control study was conducted in the VCT clinic of Sanglah General Hospital, Indonesia, between January 1 and September 1, 2016. The case group was HIV patients with ACD, while the control group was HIV patients without ACD. Purposive consecutive sampling was employed in HIV patients aged 15-65 years who have received cARV therapy for $>6$ months, had $>95 \%$ adherence of cARV within 6 months, did not have any clinical failure, did not have any immunological failure and did not receive switch therapy within 6 months. Chi-square test and logistic regression analysis were performed.

Results: A total of 42 cases and 42 controls were included in this study. Significant differences were found between case and control, which included serum IL-6, serum hepcidin, smoking, creatinine clearance, anemia at the initiation of cARV, CD4 at the initiation of cARV and actual CD4 $($ cell $/ \mu \mathrm{L})$. High levels of serum IL-6, high levels of serum hepcidin and $\mathrm{CD} 4<350$ cells $/ \mu 1$ were risk factors for ACD. After adjusted with anemia at CARV initiation and BMI, we found that high levels of serum IL-6 (adjusted OR: 17.682; 95\% CI: 3.442-90.826), high levels of serum hepcidin (adjusted OR: 10.562; 95\% CI: 2.531-44.076) and CD4 <350 cells/ $\mu$ l (adjusted OR: 4.181; 95\% CI: 5.6-12.381) remain as risk factors for ACD.

Conclusion: High levels of serum IL-6, high levels of serum hepcidin and CD4 count $<350$ cells/ $\mu \mathrm{L}$ were risk factors for ACD in HIV patients with cARV therapy.

Keywords: HIV infections, anemia, IL-6, hepcidins, CD4 cell count

\section{Introduction}

HIV infection remains a global health problem. It is estimated that number of people living with HIV infection (PLWH) has reached 34 million people. ${ }^{1}$ Among PLWH, anemia of chronic disease (ACD) is one of the hematological disorders found $\left(37.5 \%\right.$ of PLWH). ${ }^{2}$ ACD or commonly known as the anemia of inflammation is anemia that is related to chronic illness, such as HIV infection. Combination of antiretroviral (cARV) therapy may suppress HIV replication, which then leads to the recovery of the immune system. As a result of the better immune system, life expectancy and the quality of life of the patients will also increase. In other words, 
the use of cARV therapy can ameliorate anemia condition in PLWH. ${ }^{3-5}$ However, ACD is often found in PLWH who have received cARV therapy $(16.2-30.8 \%) .{ }^{6,7}$ One of the possible mechanisms through continuous inflammatory process. ${ }^{8}$

High levels of serum IL-6 were reported associated with anemia in patients with HIV who received cARV. ${ }^{9}$ The suggested mechanism how IL-6 involved in the pathogenesis of ACD is by increasing iron storage in macrophages and through the regulation of hepcidin. ${ }^{10-12}$ In ACD, hepcidin inhibits the release of iron by macrophages and iron absorption in enterocytes through internalization and degradation of ferroportin in enterocytes and macrophages. ${ }^{13,14}$ Accumulation of iron in macrophages can trigger HIV-1 transcription and replication. ${ }^{15}$ Then, the increase in transcription and replication of HIV will increase the activity of chronic inflammation and will inhibit the escalation of CD4 cell count. Moreover, hepcidin levels were found to be inversely related to the levels of CD4 cell count in the advanced stages of HIV. ${ }^{16}$

Therefore, this study aimed to determine whether high levels of serum IL-6 and hepcidin and CD4<350 cells $/ \mu \mathrm{L}$ were risk factors for ACD in PLWH on cARV therapy with successful clinically and immunological responses.

\section{Material and methods}

A matched case-control study was conducted in Voluntary Counselling and Testing (VCT) clinic of Sanglah Hospital, Denpasar, Bali, Indonesia, from January 1 to September 1, 2016. Purposive consecutive sampling was used for selecting participants. The inclusion criteria were HIV patients aged 15-65 years, who have been treated with cARV therapy for $>6$ months, have the adherence rate of $\mathrm{cARV}$ within 6 months $>95 \%$, did not have any clinical failure, did not have any immunological failure and did not receive switch therapy within 6 months. Patients with chronic renal disease, with chronic liver disease, treated for anemia in the last- 3 months, taking iron supplements in the last 3 months, with history of blood transfusion in the last 1 year, suffering from acute infection, with tuberculosis infection, with malignancy, with hepatitis $C$ virus infection, with acute hypersensitivity reaction and who were pregnant were excluded from the study.

The diagnosis of ACD was based on hemoglobin $(\mathrm{Hb})$ levels $<13 \mathrm{~g} / \mathrm{dL}$ in males or $<12 \mathrm{~g} / \mathrm{dL}$ in females, with normochromic-normocytic morphology (mean corpuscular volume [MCV] 80-96 fl and mean corpuscular hemoglobin [MCH] 27-33 pg) or hypochromic-microcytic $(\mathrm{MCV}<80 \mathrm{mg}$ and $\mathrm{MCH}<27 \mathrm{pg}$ ) with serum iron $<50 \mathrm{mg} / \mathrm{dL}$, total iron-binding capacity $(\mathrm{TIBC}) \leq 350 \mathrm{mg} / \mathrm{dL}$ and serum ferritin $\geq 30 \mathrm{ng} / \mathrm{mL}$. $^{1}$

The blood specimen was examined with high sensitivity human IL-6 in vitro ELISA, DRG Hepcidin-25 serum ELISA and CD4 cell count by flow cytometry. All data analyzed with SPSS 15.0 for Windows. All data were tested for normality with the Kolmogorov-Smirnov test. Data with normal distribution presented as mean $\pm \mathrm{SD}$, while data without normal distribution presented as median (interquartile range). The comparison test between cases and controls were carried out with Student's paired $t$-test for numerical scale data with normal distribution. The nonparametric analysis was performed with the Mann-Whitney $\mathrm{U}$ test. Chi-square test was used to assess the high levels of serum IL-6, high levels of serum hepcidin and CD4 cell count as risk factors. To classify the numeric variables into dichotomous, cutoff point value for serum hepcidin level was set at $\geq 23.2 \mathrm{ng} / \mathrm{mL}$ and $\geq 23.3 \mathrm{ng} / \mathrm{mL}$ for male and female, respectively, based on previous studies and literature. The cutoff point for serum IL-6 level was determined with receiver operating curve (ROC). OR was used for analysis of the strength of the risk factor. Correlation test between independent variables was performed with Spearman test to detect multicollinearity effect. The confounding variables were controlled by logistic regression (LR) analysis with backward method LR, which included all independent variables with a $p$-value of $<0.25$. Then, potential risk factors were analyzed using regression logistic analysis (forward method). The level of significance $(\alpha)$ in this study was set at the probability value $(p)$ of $<0.05$.

\section{Results}

\section{Characteristics of HIV-infected patients with CARV therapy based on ACD status}

A total of 84 subjects of HIV-infected patients with cARV therapy were included in this study (42 subjects with ACD and 42 subjects without ACD). The clinical characteristics are depicted in Table 1, while the laboratory biomarkers are described in Table 2. Based on Table 1, there was a statistically significant difference for smoking, classification of BMI and history of anemia at cARV initiation between case and control.

A significant difference was observed for IL-6, hepcidin and current CD4 between case and control groups (Table 2). 
Table I Clinical characteristics of Human Immunodeficiency Virus (HIV)-infected patients with cARV therapy with and without ACD

\begin{tabular}{|c|c|c|c|}
\hline Clinical characteristic of subjects & $\begin{array}{l}\text { With ACD } \\
(n=42)\end{array}$ & $\begin{array}{l}\text { Without ACD } \\
(n=42)\end{array}$ & $p$-value* \\
\hline Age (years), median (Interquartile Range [IQR]) & $39(32-50.00)$ & $39.5(32-47.25)$ & $0.792 * *$ \\
\hline \multicolumn{4}{|l|}{ Sex, n (\%) } \\
\hline Male & $15(35.72)$ & 15 & 1.000 \\
\hline Female & $27(64.28)$ & 27 & \\
\hline Height $(\mathrm{cm})$, median (IQR) & $160(155-165)$ & $159.5(152-165)$ & $0.368 * *$ \\
\hline Body weight $(\mathrm{kg})$, median (IQR) & $52.50(47-60)$ & $54.50(48.75-65.00)$ & $0.329 * *$ \\
\hline Body Mass Index (BMI) $\left(\mathrm{kg} / \mathrm{m}^{2}\right)$, median (IQR) & $19.87(18.38-22.92)$ & $22.74(19.7 I-24.89)$ & $0.063^{* *}$ \\
\hline \multicolumn{4}{|l|}{ Classification of BMI, n (\%) } \\
\hline Underweight & II (26.2) & $4(9.5)$ & 0.013 \\
\hline Ideal & $22(52.4)$ & $21(50.0)$ & \\
\hline Overweight & I (2.4) & $10(23.8)$ & \\
\hline Obese & $8(19.0)$ & $7(16.7)$ & \\
\hline Smoking, n (\%) & $4(9.5)$ & II (26.2) & 0.046 \\
\hline Alcohol, n (\%) & I (2.4) & $4(9.5)$ & 0.167 \\
\hline History of IVDU, n (\%) & I (2.4) & I (2.4) & 1.000 \\
\hline Length of HIV infection (month), median (IQR) & $24.50(12.00-69.50)$ & $39.50(15.75-57.50)$ & $0.368 * *$ \\
\hline History of anemia at cARV initiation, $n(\%)$ & $38(90.47)$ & $18(42.85)$ & $<0.001$ \\
\hline Length of cARV therapy (month), median (IQR) & $18.50(10.50-56.25)$ & $32.50(15-52.25)$ & $0.187 * *$ \\
\hline History of opportunistic infection before cARV, n (\%) & $25(59.52)$ & $27(64.28)$ & 0.653 \\
\hline History of TB before cARV, $n(\%)$ & $3(7.14)$ & $5(11.90)$ & 0.457 \\
\hline \multicolumn{4}{|l|}{ Regiment of cARV, n (\%) } \\
\hline$A Z T+3 T C+N V P$ & $6(14.28)$ & $9(21.4)$ & 0.736 \\
\hline $\mathrm{AZT}+3 \mathrm{TC}+\mathrm{EFV}$ & $4(9.5)$ & $2(4.8)$ & \\
\hline $\mathrm{TDF}+3 \mathrm{TC}+\mathrm{NVP}$ & $6(14.28)$ & $7(16.7)$ & \\
\hline TDF+3TC+EFV & $24(57.14)$ & $22(52.4)$ & \\
\hline TDF+3TC+ lopinavir + ritonavir & $2(4.8)$ & I (2.4) & \\
\hline $\mathrm{AZT}+3 \mathrm{TC}+$ lopinavir + ritonavir & $0(0)$ & I (2.4) & \\
\hline
\end{tabular}

Notes: *Chi-square test; **Mann-Whitney $U$ test.

Abbreviations: IVDU: Intravenous drugs user; cARV, combination of antiretroviral; ACD, anemia of chronic disease; AZT, zidovudine; 3TC, lamivudine; NVP, nevirapine; EFV, efavirenz; TDF, tenofovir disoproxil fumarat; TB, tuberculosis.

\section{Serum IL-6, hepcidin and CD4 cell count} as risk factors for ACD in HIV patients with CARV therapy

Serum IL-6 was the most powerful biomarker for risk factors of anemia in HIV patients with cARV (OR 10.45, 95\% CI 3.163-34.52), followed by serum hepcidin and CD4 cell count (Table 3).

Prior to multivariate analysis, all variables that will be fitted into the model were tested for correlation to determine the effect of multicollinearity. The results of correlation test indicated that none of correlation between the independent variables was strongly correlated $(r>0.5)$, so that all the independent variables can be included in a LR model. LR analysis was then performed as backward LR elimination method, to assess the effect of each variable after accounting for confounding variables.

After analysis of several confounding variables, the result for the role of IL-6, hepcidin and CD4 purely as risk factors are shown in Table 4. IL-6 was the most powerful biomarker risk factor for ACD.

\section{Multiple LR analysis of serum IL-6, serum hepcidin and CD4 cell count as risk factors for ACD in HIV patients with CARV therapy}

In the multiple LR analysis, the role of serum IL-6, serum hepcidin and CD4 cell count were fitted simultaneously as the risk of ACD, as shown in Table 5. 
Table 2 The characteristic of laboratory biomarkers of HIV-infected patients with cARV therapy with and without ACD

\begin{tabular}{|c|c|c|c|}
\hline Laboratory characteristic of subjects & $\begin{array}{l}\text { With ACD } \\
(n=42)\end{array}$ & $\begin{array}{l}\text { Without ACD } \\
(n=42)\end{array}$ & $P$-value* \\
\hline $\mathrm{Hb}(\mathrm{g} / \mathrm{dL})$, median (IQR) & $11.40(10.76-12.06)$ & $13.72(|2.59-| 4.87)$ & $<0.001$ \\
\hline Male & $12.70(11.00-12.82)$ & $15.20(14.70-15.90)$ & $<0.001$ \\
\hline Female & $11.30(10.30-11.70)$ & $12.90(12.40-13.70)$ & $<0.001$ \\
\hline MCV (fl), median (IQR) & $95.75(89.67-99.05)$ & $95.50(90.9-104.70)$ & 0.174 \\
\hline $\mathrm{MCH}(\mathrm{pg})$, median $(\mathrm{IQR})$ & $30.30(27.52-31.42)$ & $31.40(29.90-36.72)$ & 0.013 \\
\hline Serum creatinin $(\mathrm{mg} / \mathrm{dL})$, mean $\pm \mathrm{SD}$ & $0.78 \pm 0.16$ & $0.74 \pm 0.17$ & $0.24 * *$ \\
\hline Creatinine clearance $(\mathrm{mL} / \mathrm{mnt})$, median (IQR) & $86.53(65.27-99.64)$ & $98.804(79.96-108.9)$ & 0.013 \\
\hline $\mathrm{Hb}(\mathrm{g} / \mathrm{dL})$ at $\mathrm{cARV}$ initiation, median (IQR) & $11.05(10.17-11.75)$ & $12.20(10.75-13.55)$ & 0.003 \\
\hline Male, median (IQR) & $11.40(10.70-12.00)$ & $13.17(11.30-15.10)$ & 0.004 \\
\hline Female, median (IQR) & $10.90(10.00-11.70)$ & $11.50(10.10-12.70)$ & 0.076 \\
\hline CD4 at $c A R V$ initiation (cell/ $\mu \mathrm{L}$ ), median (IQR) & $60(12.25-172.50)$ & $126(44.55-202.50)$ & 0.027 \\
\hline IL-6 (pg/mL), median (IQR) & $4.03(1.69-8.49)$ & $1.92(1.42-3.09)$ & 0.001 \\
\hline Hepcidin (ng/mL), median (IQR) & 23.55 (6.58-49.99) & $7.61(4.72-14.14)$ & 0.002 \\
\hline Male, median (IQR) & $45.24(32.11-76.14)$ & II.73 (7.27-| 7.53$)$ & $<0.001$ \\
\hline Female, median (IQR) & $12.40(2.99-37.75)$ & $7.06(3.74-10.47)$ & 0.100 \\
\hline Current CD4 (cell/ $\mu \mathrm{L})$, mean \pm SD & $331.476 \pm 177.84$ & $480.476 \pm 223.73$ & $0.001 * *$ \\
\hline
\end{tabular}

Notes: *Mann-Whitney $U$ test; **Student's $t$-test.

Abbreviations: $C A R V$, combination of antiretroviral; ACD, anemia of chronic disease.

Table 3 Bivariate analysis (Chi-square) of serum IL-6 level, hepcidin and CD4 cell count as risk factors for ACD in HIV with cARV

\begin{tabular}{|c|c|c|c|c|c|}
\hline Variables & $\begin{array}{l}\text { ACD } \\
(n=42)\end{array}$ & $\begin{array}{l}\text { Without ACD } \\
(n=42)\end{array}$ & OR & $p$-value & $95 \% \mathrm{Cl}$ \\
\hline IL-6 $23.98 \mathrm{pg} / \mathrm{mL}$ & $22(52.4 \%)$ & $4(9.5 \%)$ & 10.45 & $<0.001$ & $3.163-34.52$ \\
\hline $\begin{array}{l}\text { Hepcidin } \\
\qquad \text { Male } \geq 23.2 \mathrm{ng} / \mathrm{mL} \\
\text { Female } \geq 23.3 \mathrm{ng} / \mathrm{mL}\end{array}$ & 21 (50\%) & 5 (11.9\%) & 7.4 & $<0.001$ & $2.432-22.514$ \\
\hline CD4<350 cells/Ul & $26(61.9 \%)$ & 14 (33.3\%) & 3.25 & 0.009 & I.329-7.94 \\
\hline
\end{tabular}

Abbreviation: ACD, anemia of chronic disease.

Table 4 Multiple logistic regression tests on levels of serum IL-6, serum hepcidin and CD4 cell count as anemia of chronic disease risk factors in HIV-infected patients on cARV therapy, after controlling for confounding variable

\begin{tabular}{|l|l|l|l|}
\hline Variables & Adjusted OR & p-value & $\mathbf{9 5 \%} \mathbf{C l}$ \\
\hline $\mathrm{IL}-6 \geq 3.98 \mathrm{pg} / \mathrm{mL}$ & 17.682 & 0.001 & $3.442-90.826$ \\
Hepcidin & 10.562 & 0.001 & $2.531-44.076$ \\
$\quad \begin{array}{l}\text { male } \geq 23.2 \mathrm{ng} / \mathrm{mL} \\
\text { female } \geq 23.3 \mathrm{ng} / \mathrm{mL}\end{array}$ & & & \\
$\mathrm{CD} 4<350 \mathrm{cells} / \mu \mathrm{L}$ & $4.18 \mathrm{I}$ & 0.010 & $5.6-12.38 \mathrm{I}$ \\
\hline
\end{tabular}

The result showed that high levels of serum IL-6 ( $\geq 3.98 \mathrm{pg} / \mathrm{mL}$ ) was a more powerful biomarker compared to serum hepcidin and CD4 cell count as risk factors for ACD in HIV-infected patients treated with $\mathrm{CARV}$ with clinical and immunological improvement.

\section{Discussion}

The use of cARV therapy has dramatically decreased morbidity and mortality of PLWH. To date, the effect of cARV therapy on inflammatory biomarkers was still not clearly known. ${ }^{9}$ Dysfunctions of monocytes occur in PLWH treated with cARV, which has led to a higher level of serum IL- 6 compared to healthy adults and the elderly population. ${ }^{17,18}$ In particular, mean plasma level of IL-6 is higher in the HIV-infected patients (2.14 $\mathrm{pg} / \mathrm{mL})$ compare to HIV-negative participants $(1.47 \mathrm{pg} / \mathrm{mL}){ }^{18}$ In their study, Borges et al found that serum IL-6 associated with anemia in HIV-infected patients with cARV therapy. ${ }^{19}$ Moreover, Kerkhoff et al found that the serum level of IL-6 was associated with the severity of ACD in patients with HIV and tuberculosis. ${ }^{20}$ In contrast, Lipshultz et al (2015) reported that IL-6 was 
Table 5 Multiple logistic regression of serum IL-6, serum hepcidin and CD4 cell count on anemia of chronic disease in HIVinfected patients with CARV therapy

\begin{tabular}{|c|c|c|c|}
\hline Variables & $\begin{array}{l}\text { OR } \\
\text { Exp } \\
\text { (B) }\end{array}$ & $\begin{array}{l}p- \\
\text { value }\end{array}$ & $95 \% \mathrm{Cl}$ \\
\hline $\mathrm{IL} 6 \geq 3.98 \mathrm{pg} / \mathrm{mL}$ & 6.529 & 0.005 & I.747-24.392 \\
\hline $\begin{array}{l}\text { Hepcidin } \\
\text { male } \geq 23.2 \mathrm{ng} / \mathrm{mL} \\
\text { female } \geq 23.3 \mathrm{ng} / \mathrm{mL}\end{array}$ & 3.838 & 0.039 & $1.073-13.725$ \\
\hline CD4 cell count $<350$ cells $/ \mu \mathrm{L}$ & 3.252 & 0.026 & I. $148-9.207$ \\
\hline
\end{tabular}

not an independent predictor of anemia and mild anemia in HIV patients with cARV therapy. ${ }^{21}$ However, a study with fewer participants has concluded that serum IL-6 did not show significant correlation with anemia on PLWH on cARV therapy. ${ }^{22}$

The current study found that IL-6 was significantly higher in PLWH with cARV therapy and ACD, compared to PLWH without ACD. This study also found that the high level of serum IL-6 was a risk factor for ACDs, such as anemia in other underlying chronic diseases. This finding is consistent with the pathogenesis of ACD in general, in which IL-6 is estimated to play a role through translational and transcriptional induction of ferritin, thereby increasing iron stores in the reticuloendothelial system (RES) and through increased hepcidin by hepatocyte cells. ${ }^{11,23}$ This also concurred with results of other studies on patients with ACD in some underlying chronic diseases, which found that IL-6 affects the ACD through hepcidin. ${ }^{24}$

Wisaksana et al found that levels of serum hepcidin inversely related to hemoglobin level in patients with HIV infection. ${ }^{16}$ Minchella et al found that median levels of serum hepcidin in HIV-infected patients with anemia were higher compared to those without anemia (32.2 vs $6.8 \mathrm{ng} /$ $\mathrm{mL} ; p$ : 0.06), but the population of the study was not specific on HIV-infected patients treated with $\mathrm{cARV}^{25}$ Furthermore, in a study that aimed to compare patterns of hepcidin and iron regulation between HIV-negative and HIV-infected patients, the mean plasma level of hepcidin was higher in HIV-infected $(19.13 \mathrm{ng} / \mathrm{mL})$ than in HIVnegative $(8.35 \mathrm{ng} / \mathrm{mL})$ patients. ${ }^{18}$ Moreover, patients with chronic kidney disease who had higher ferritin level have a higher mean plasma level of hepcidin compared to those with lower ferritin level. ${ }^{26}$ The same results were also found in a study conducted by Kerkhoff et al which reported that serum hepcidin levels were associated with the severity of anemia and a strong predictor of mortality in HIV-TB co-infected patients. ${ }^{27}$ Likewise, Kerkhoff et al found that levels of serum hepcidin were associated with the severity of ACD in HIV-TB co-infected patients. ${ }^{20}$ Those results were consistent with this study, in which the median level of serum hepcidin was higher in ACD than without ACD in HIV-infected patients on cARV therapy. In this study, PLWH with a high level of serum hepcidin has 7.4 times higher risk for ACD in HIVinfected patients treated with cARV. The role of hepcidin in ACD is through the disturbance of iron traffic that followed with a decrease of iron absorption in the duodenum and inhibits the release of iron from macrophages. ${ }^{11}$

Anemia is more common in patients with a low CD4 cell count $(<200$ cells $/ \mu \mathrm{L}){ }^{2}$ Longitudinal studies in women found that CD4 cell count of $<200$ cells/ $\mu \mathrm{L}$ was a risk factor for anemia in HIV-infected patients (OR 1.68; 95\% CI 1.46-1.94). ${ }^{28} \mathrm{~A}$ cohort study in South Africa found that a low CD4 cell count (CD4 $<50$ cells $/ \mu \mathrm{L}$ ) was a risk factor for anemia during cARV therapy. ${ }^{29}$ In this study, we found that low CD4 cell counts $(<350$ cells $/ \mu \mathrm{L})$ were a risk factor for $\mathrm{ACD}$ in HIV patients who received cARV (OR 3.25; 95\% CI: 1.329-7.947; $p=0.009$ ).

This study was subject to some limitations. First, we did not assess HIV viral load since these examinations are not part of the routine examination for PLWH in Indonesia, a developing country in South-East Asia. ${ }^{30}$ In addition, the laboratory examinations are not available in Bali so they must be referred to Jakarta, the capital city of Indonesia. As a result, the extent of viral load's role in affecting levels of serum IL-6, serum hepcidin, and CD4 cell count was not measured. To control the effect of HIV viral load to this study, we have applied tight inclusion criteria through the selection of patients who received cARV more than 6 months, the level of adherence of cARV $>95 \%$, an improvement of clinical and immunological, and never experienced switch therapy within 6 months due to treatment failure. Second, we have excluded participants with tuberculosis infection since tuberculosis infection can influence the level of IL-6 and serum hepcidin as a confounding factor. We have excluded tuberculosis infection using physical examination, acid-fast bacilli, Gene Xpert and chest roentgen. However, we cannot exclude latent tuberculosis since it will need more advanced examinations, such as interferon-gamma release assay. These examinations are not available in Bali, and they are not part of the standard of care in managing PLWH. ${ }^{30}$ 


\section{Conclusion}

High levels of serum IL-6, high levels of serum hepcidin and CD4 count $<350$ cells $/ \mu \mathrm{L}$ were risk factors for ACD in HIV patients with cARV therapy. It is to be hoped that further studies can include HIV viral load in their analysis and can also exclude latent tuberculosis from their participants.

\section{Ethics Statement}

The study was conducted in accordance with the Declaration of Helsinki and the principles of Good Clinical Practice. All patients provided written informed consent to include their clinical and biological data in our study. The study was approved by the ethics committee of Udayana UniversitySanglah General Hospital with ethical clearance No: 109/ UN.142/R \& D/2016.

\section{Acknowledgments}

I wish to thank all of the participants and team of Nusa Indah VCT-CST clinic Sanglah General Hospital for their cooperation and support for this research, clinical pathology laboratory of Sanglah General Hospital Denpasar Bali and Prodia Laboratory of Denpasar Bali for storage and specimens examination.

\section{Disclosure}

This research did not receive any specific grant from funding agencies in the public, commercial or not-for-profit sectors. The authors report no conflicts of interest in this work.

\section{References}

1. Cullis JO. Diagnosis and Management of Anaemia of Chronic Disease: Current Status. British Journal of Haematology. 2011;154:289-300.

2. De Santis GC, Brunetta DM, Vilar FC, et al. Hematological abnormalities in HIV-infected patients. Int $J$ Infect Dis. 2011;15(12):e808. doi:10.1016/j.ijid.2011.08.001

3. Berhane HK, Karim HR, Cohen MM, et al. Impact of highly active antiretroviral therapy on anemia and relationship between anemia and survival in a large cohort of HIV-infected women: women's interagency HIV study. J Acquir Immune Defic Syndr. 2004;37(2):1245-1252.

4. Mocroft A, Lifson A, Touloumi G, et al. Haemoglobin and anaemia in the SMART study. Antivir Ther. 2011;16(3):329-337. doi:10.3851/ IMP1746

5. Ndlovu Z, Chirwa T, Takuva S. Incidence and predictors of recovery from anaemia within an HIV-infected South African cohort, 2004-2010. Pan Afr Med J. 2014;19:114

6. Wibawa KR, Merati TP. Factors Related with Macrocytosis in HIV/ AIDS Patients on Zidovudine Therapy at Sanglah Hospital Denpasar Bali Indonesia. Bali: Udayana University; 2010;1-10.

7. Gedefaw L, Sahlemariam Z, Anemia YD. Risk factors in HAART Naïve and HAART experienced HIV positive persons in South West Ethiopia: a comparative study. PLoS One. 2013;8(8):e72202. doi:10.1371/journal.pone. 0072202
8. Redig AJ, Berliner N. Pathogenesis and clinical implications of HIV-related anemia in 2013. Hematology Am Soc Hematol Educ Program. 2013;2013(1):377. doi:10.1182/asheducation2013.1.377

9. Borges HÁ, Weitz IJ, Collins VG, et al. Markers of inflammation and activation of coagulation are associated with anaemia in antiretroviral-treated HIV disease. AIDS. 2014;28(12):1791-1796. doi:10.1097/QAD.0000000000000344

10. Andrews NC. Anemia of inflammation: the cytokine-hepcidin link. $J$ Clin Invest. 2004;113(9):1251-1253. doi:10.1172/JCI21441

11. Weiss G, Goodnough LT. Anemia of chronic disease. $N$ Engl J Med. 2005;352(10):1011-1059. doi:10.1056/NEJMra041809

12. Poggiali E, De Amicis MM, Motta I. Anemia of chronic disease: A unique defect of iron recycling for many different chronic diseases. Eur $J$ Intern Med. 2014;25(1):12-17. doi:10.1016/j. ejim.2013.07.011

13. Drakesmith H, Prentice A. Hepcidin and the iron-infection axis. Science. 2012;338(6108):768-772. doi:10.1126/science.1224577

14. D'Angelo G. Role of hepcidin in the pathophysiology and diagnosis of anemia. Blood Res. 2013;48(1):10. doi:10.5045/ br.2013.48.1.10

15. Turner W, Rotimi J, Foster A, et al. Hepcidin induces HIV-1 transcription inhibited by ferroportin. Retrovirology. 2010;7(1):104. doi:10.1186/1742-4690-7-104

16. Wisaksana R, de Mast Q, Alisjahbana B, et al. Inverse relationship of serum hepcidin levels with CD4 cell counts in HIV-infected patients selected from an Indonesian prospective cohort study. PLoS One. 2013;8(11):e79904. doi:10.1371/journal.pone.0079904

17. De Pablo-Bernal RS, Ramos R, Genebat M, et al. Phenotype and polyfunctional deregulation involving interleukin 6 (IL-6)- and IL10-producing monocytes in HIV-infected patients receiving combination antiretroviral therapy differ from those in healthy older individuals. J Infect Dis. 2016;213(6):999-1007. doi:10.1093/infdis/ jiv520

18. Armitage AE, Stacey AR, Giannoulatou E, et al. Distinct patterns of hepcidin and iron regulation during HIV-1, HBV, and HCV infections. Proc Natl Acad Sci U S A. 2014;111(33):12187. doi:10.1073/pnas. 1402351111

19. Borges ÁH, O’Connor JL, Phillips AN, et al. Factors associated with plasma IL-6 levels during HIV infection. $J$ Infect Dis. 2015;212 (4):585-595. doi:10.1093/infdis/jiv123

20. Kerkhoff AD, Meintjes G, Opie J, et al. Anaemia in patients with HIV-associated TB: relative contributions of anaemia of chronic disease and iron deficiency. Int $J$ Tuberc Lung Dis. 2016;20 (2):193-201. doi:10.5588/ijtld.15.0558

21. Lipshultz HM, Hileman CO, Ahuja S, Funderburg NT, McComsey G. Anaemia is associated with monocyte activation in HIV-infected adults on antiretroviral therapy. Antivir Ther. 2015;20(5):521-527. doi:10.3851/IMP2940

22. Quiros-Roldan E, Castelli F, Lanza P, et al. The impact of antiretroviral therapy on iron homeostasis and inflammation markers in HIV-infected patients with mild anemia. $J$ Transl Med. 2017;15(1):256.

23. Raj D. Role of interleukin-6 in the anemia of chronic disease. Semin Arthritis Rheum. 2009;38(5):382-388. doi:10.1016/j. semarthrit.2008.01.006

24. Ketut S. Role of hepcidin in mechanism of anemia chronic disease patients. Bali Med J. 2014;3(2):89-96.

25. Minchella PA, Armitage AE, Darboe B, et al. Elevated hepcidin is part of a complex relation that links mortality with iron homeostasis and anemia in men and women with HIV infection. $J$ Nutr. 2015;145 (6): 1194 . doi:10.3945/jn. 114.203158

26. Suzuki A, Kawabata H, Mitsumoto K, et al. Serum hepcidin-25 levels predict the progression of renal anemia in patients with non-dialysis chronic kidney disease. Nephrol Dial Transplant. 2012;27 (12):4378-4385. doi:10.1093/ndt/gfs322 
27. Kerkhoff AD, Meintjes G, Burton R, Vogt M, Wood R, Lawn SD Relationship between blood concentrations of hepcidin and anemia severity, mycobacterial burden, and mortality among patients with HIV-associated tuberculosis. J Infect Dis. 2016;213(1):61. doi:10.1093/infdis/jiv364

28. Semba RD, Shah N, Klein RS, Mayer KH, Vlahov D. Prevalence and cumulative incidence of and risk factors for anemia in a multicenter cohort study of human immunodeficiency virus-infected and Uninfected women. Clin Infect Dis. 2002;34(2):260-266. doi:10.1086/ 338151
29. Takuva S, Maskew M, Brennan AT, Sanne I, MacPhail AP, Fox MP. Anemia among HIV-infected patients initiating antiretroviral therapy in South Africa: improvement in hemoglobin regardless of degree of immunosuppression and the initiating ART regimen. J Trop Med. 2013;2013(2013):1-6. doi:10.1155/2013/162950

30. Indonesian Society of Internal Medicine (PAPDI). Clinical Practice Guideline (Panduan Praktik Klinis). Jakarta:Interna Publishing; 2015;200-300.

\section{Publish your work in this journal}

HIV/AIDS - Research and Palliative Care is an international, peerreviewed open-access journal focusing on advances in research in $\mathrm{HIV}$, its clinical progression and management options including antiviral treatment, palliative care and public healthcare policies to control viral spread. The manuscript management system is completely online and includes a very quick and fair peer-review system, which is all easy to use. Visit http://www.dovepress.com/testimonials.php to read real quotes from published authors. 